Int. J. Electrochem. Sci., 13 (2018) 8589 - 8601

\title{
Electricity Generation from Heavy Metal-Containing Wheat Grain Hydrolysate Using Single-Chamber Microbial Fuel Cells: Performance and Long-Term Stability
}

\author{
Guang-En Yuan, Honghu Deng, Xiangli Ru, Xin Zhang *
}

School of Environment, Henan Normal University, Key Laboratory for Yellow River and Huai River Water Environmental and Pollution Control, Ministry of Education, Henan Key Laboratory for Environmental Pollution Control, Xinxiang, Henan 453007, PR China.

*E-mail: xinzhang2015@126.com

doi: $10.20964 / 2018.09 .05$

Received: 12 June 2018 / Accepted: 4 July 2018 / Published: 5 August 2018

In this study, heavy metal-containing wheat grain (HMWG) hydrolysate was explored as a potential fuel in membrane-less single chamber microbial fuel cells (MFCs) for electricity production. The maximum coulombic efficiency got up to $15.7 \%$, and the corresponding removal rate of chemical oxygen demand was $83.4 \%$. A maximum power density of $381 \mathrm{~mW} / \mathrm{m}^{2}$ was achieved with relatively low concentration of the HMWG hydrolysate, but high concentration of the HMWG hydrolysate restrained the electricity production in a MFC, especially after long-terms of operation. The results of electrochemical analysis and scanning electron microscope proved that the decreased performance in electricity generation was mainly ascribed to the declined electrocatalytic activities of the MFC anode and the attenuated microorganisms on its surface. The present work demonstrates that attention should be paid to the toxicity of heavy metals in energy recovery from heavy metal-containing organic wastes by MFCs.

Keywords: Microbial fuel cell; Heavy metal; Organic waste; Electricity generation; Long-term stability

\section{$\underline{\text { FULL TEXT }}$}

(C) 2018 The Authors. Published by ESG (www.electrochemsci.org). This article is an open access article distributed under the terms and conditions of the Creative Commons Attribution license (http://creativecommons.org/licenses/by/4.0/). 